\title{
The Petro-Dominant Economy,“'Resource Curse` Thesis And Consequences on The Development of Enterprise And Entrepreneurship in Nigeria
}

\author{
Dr. MB Umar ${ }^{1}$, Sulaiman Ibrahim Kassim² \\ ${ }^{1}$ Centre for Entrepreneurship Development, Federal University Dutse, Jigawa State \\ ${ }^{2}$ Centre for Entrepreneurship Development, Federal University Dutse, Jigawa State
}

\begin{abstract}
The proven link between Enterprise/Entrepreneurship Development and economic Growth necessitated the struggle towards instilling entrepreneurial mindsets and the creation of conducive atmosphere in which enterprises and entrepreneurial culture could grow in many great economies of the world. In Nigeria, the emergence entrepreneurial mindsets have been more strong in the last three to four decades especially in Industry, Agriculture, Manufacturing and some aspects of small business but with the discovery of oil in commercial quantity, the trend began to deteriorate. This paper interrogates the effect of Natural Resources on the development of a nation and how it impacted more specifically on enterprise and entrepreneurship. The study utilizes extensive literature survey to find and establish the relationship between the variables under study. The finding reveals that the country has perpetually squandered it's oil money making it unable to create a strong base for viable enterprises and entrepreneurship to thrive and as a result making the populace to move more towards paid employment especially where 'easy money' can be obtained in certain circumstances This has resulted in the creation of a mono-cultured economy and the consequent levity in stimulating Agriculture, Manufacturing and other entrepreneurial endeavors. The paper has, thus, recommended that an imaginative leadership with a clear vision and willpower to change the course in terms of public spending; changing people's mindset, and curbing corruption is fundamentally required. That will enable the government to redirect it spending in strengthening our enterprises and entrepreneurship creating institutions and by implication creating a conducive atmosphere for their growth and development.
\end{abstract}

Keywords: Entrepreneurship, Entrepreneurial Development, Entrepreneurial Mindset, Natural Resources, Resource Curse.

\section{Introduction}

Before the discovery of oil, Nigeria was famous for her agrarian economy through which cash crops like palm produce (oil and kernel), cocoa, rubber, and timber, groundnut, e.t.c were exported, thus making her a major exporter in that respect. Indeed, agriculture was the bedrock of Nigeria's economic development which employed over seventy percent $(70 \%)$ of the labour force. It also provided the basic food requirements for Nigerians, as well as raw materials for local industries. The exportation of the agricultural products also culminated in the development of infrastructures, particularly in the health and educational sectors; with the establishment of universities and hospitals (1985, Carland). Apart from agriculture small trade and small business in form of Dyeing, Blacksmith, Tailoring, Shoemaking, Barbing, Knitting, Weaving and Merchandising thrives in most part of the country, these trades employ significant portion of the population (1985, Carland). The general investment atmosphere was characterized by low corruption, low robbery, no kidnapping, electricity was more stabilize, inflation and poverty were controllable.

Njeze, Cally (1978) show that Early indications of the presence of crude oil in Nigeria was witnessed when oil seepage were seen at Araromi in the present Ondo State. Encouraged by this development, a German company, "Nigeria Bitumen Corporation" was contracted to explore for oil in 1908. This pioneering effort was interrupted by the outbreak of World War (1914-1918) but after the war, nothing was heard of the oil industry. In 1937, an Anglo Dutch consortium Shell D' Archy, the fore- runner of Shell Petroleum Development Company (SPDC) of Nigeria embarked on another exploration. Unfortunately like the previous effort, its activities were interrupted by yet another war, the Second World War (1939-1945) and exploration did not resume in Nigeria till ten years later. After many years of search and an initial investment of over 30 million naira, oil was discovered in 1956 in commercial quantity at Oloibiri, in present day Bayelsa State by Shell Petroleum Development Company (SPDC). Nigeria joined the ranks of oil producers in 1958 when its first oil field came on stream producing 5,100 barrels per day. After 1960, exploration rights in onshore and offshore areas adjoining the Niger Delta were extended to other foreign companies.

In 1970, Nigeria was able to reap instant riches from its oil production. The country joined the Organisation of Petroleum Exporting Countries (OPEC) in 1971 and established the Nigerian National Petroleum Company (NNPC) in 1977, a state owned and controlled company which is a major player in both the 
The Petro-Dominant Economy, ‘Resource Curse`Thesis And Consequences On The Development ..

upstream and downstream sectors. By the late 1960s and early 1970s, Nigeria had attained a production level of over 2 million barrels of crude oil per day. Since Nigeria`s oil boom of 1970`s when the president then asserted that the problem of Nigeria is not money but how to spend it, it problem began. Huge oil revenue that time made the government to see no reason for creating asset base, the government then could employ so many people, secondary school lever could be offered a job that attract the populace into paid employment abandoning the business and agricultural sector. Although production figures dropped in the eighties due to economic slump, 2004 saw some improvements in oil production to a record level of 2.5 million barrels per day. But with all these the country has been bedeviled with enormous challenges. In a column of Daily Trust May 24, 2006 demonstrate that there is huge unemployed youth in the country, posing as a threat to the nation, the Government now cannot employ all that needs job unlike in 1970`s during the oil boom. In separate reports, the National Institute for Social Research (NISER) and the World Bank revealed that over 55 per cent of Nigerians of working age are unemployed, representing one in five adults. The World Bank report also indicated that only one in every ten graduates get a job while a recent report by the National Directorate of Employment (NDE) indicated that over 200,000 Nigerian graduates who completed the National Youth Service Corps (NYSC) in the last five years, remained unemployed.. That oil money that was realized over the years was squandered. This has necessitated the country to inject Entrepreneurship Training into educational system (Ihugba, Odii, Njoku, 2013). In the last decade more Nigerians have attended entrepreneurial trainings, taken courses in entrepreneurship than ever before. Virtually all young graduates have been tutored. With all this in place, however, the success rate of small and medium enterprises has been very low; businesses have barely survived, let alone thrived beyond incubation period. Some have down-sized to the barest minimum; others press on in anticipation of a better tomorrow, yet many more have been frustrated to closure. Government regulations and policies, insecurity and a seemingly irredeemable power sector haven't made it any easier. Nonetheless, some businesses have broken through the ice to become successful amidst the apparent national gloom (Obiajuru, 2012). This is as a result of bloated investment atmosphere, massive corruption, the money meant to provide road, security, electricity, water, hospital, school and other vital things needed provided a good climate for business were stolen by few, this made the cost doing business very high. It has been reported in Daily Trust May 24, 2016 that People are attracted to government job in the name of guarantee or security not knowing that the security has fade or eroded. The mono-cultured nature of Nigeria was proved in 2015 to date (2016) when the crude price fell below 50 Dollar per barrel causing serious economic hardship.

\section{Theoretical Framework}

A Dutch Disease is a phenomena evidently operating in Nigeria. The concept which was first found in Dutch in 1950's when crude was discovered followed by collapse of manufacturing and agricultural activities. It has been opined by Sagagi (2005) that oil exporting countries such as OPEC members with huge oil revenue have persistently experience economic hardship on the other hand resource poor countries like Japan, Taiwan, Korea, Singapore and Denmark and more others present an impressive economic growth which result in enormous investment by the citizens. In the opinion of Sachs and Warner (1995) as cited in Sagagi (2005) countries that are poor in natural resources have more energy, discipline, focus and enthusiasm for accomplishing great economic performance over those countries that are endowed with natural resources. This is as a result of negative effect of export boom from the natural resources to the economy. The phenomena create expansion in non-traded goods sector and strangulating non-oil traded goods sector, it is this that cause de-industrialization (Corden \& Neary, 1983). It is this that led to the abandonment of (traded) industrial and agricultural sector and concentration of (non-traded) sector construction and services. Although, other countries that are rich in Natural Resource where evidence of Dutch Disease is not apparent, these countries have strengthened their institutions and have created a good atmosphere for entrepreneurship.

The following table present contribution of some sectors to GDP as at fourth quarter of 2014.

Oil Sector $8.97 \%$

Non-oil Sector

$6.44 \%$

Agriculture

$6.28 \%$

The above presentation shows that oil sector was dominant in terms earning to GDP were as agric is the least in contributing to Nigeria`s GDP. According to Dike (2002) the vital thing that strengthened Dutch Disease in Nigeria and made it had to reverse it is the extreme level of corruption. Corruption destroy investment government expenditure, economic growth etc and private investment (local or foreign) (Mauro, 1997). This is true in Nigeria given it low performance and waste or embezzlement of public fund. Daily Trust of May 24, 2016 reports how state governments are spending billions on legislator's luxury cars, and National Assembly spending over 7 billion on expensive cars. In 2015 billion of Dollars were shared for campaign to win the election (Daily Trust, May 11, 2016). All these came at a time when the Mega Watt was below 2000, when 
The Petro-Dominant Economy, ‘Resource Curse`Thesis And Consequences On The Development ..

Boko Haram is displacing thousands from their home in North-east and Niger-Delta were suffering from land degradation, could not fish, when entrepreneurs could not afford loan from the bank as a result of high interest rate, the country is spending billions for importation of different kind of goods or services. How would entrepreneurship thrive in this kind of atmosphere?. Currently, majority of Nigeria`s 36 state owe workers between one to nine month unpaid salaries (Daily Trust, May 11, 2016). Spending billion of Naira on law maker's vehicle at the time when most the state government are unable to pay workers and carry basic function of government. The CBN approved N338 billion loans to 27 states to pay outstanding salaries at nine percent interest for 20 years period. Most of the 23 state that got the bailout fund diverted it for other purpose. This requires the development of a strategic agenda to build human capital, undertake economic diversification and combat corruption together with the apparent counter-productive practices bedeviling the countries Sagagi (2005). This way is the most effective in converting crude fund into enormous wealth in the country.

\section{Conclusion}

The Nigerian economy relies only on petroleum as the bedrock of the economy. Evidently, the cash crunch occasioned by fall in oil prices makes the country suffer a lot financially. Although there has been a huge amount of cash coming in of petroleum export money into the country, that did not do well for the country as it has resulted in imports and abandonment of local products, corruption and embezzlement . Massive importation and mega export affects resources that could be used in creating atmosphere for entrepreneurship. These together with massive corruption bloated the investment atmosphere for entrepreneurship. This is as result of forsaking non-oil sector, lack of investment in technology and inability to create unique competence that would enable the country create a strong base for entrepreneurship. In the same vein local entrepreneurs are suffering because of aforementioned challenges.

\section{Recommendation}

It is recommended that an imaginative leadership with a clear vision and willpower to change the course in terms of public spending; changing people's mindset, and curbing corruption is fundamentally required. That will enable the government to redirect it spending in strengthening our enterprises and entrepreneurship, creating institutions and by implication creating a conducive atmosphere for their growth and development.

\section{Reference}

[1]. Aigboduwa, J.E., Oisamoje, M.D. (2013). Promoting small and medium enterprises in the Nigerian oil and gas industry. European Scientific Journal, $1(1)$

[2]. Carland, John M (1985.). The Colonial Office and Nigeria, 1898-1914. Basingstoke: Macmillan Daily Trust May 24, 2016 Daily Trust May 11, 2016

[3]. Dike, V.E. (2002). Corruption in Nigeria: A new paradigm for effective control. Africa Economic Analysis. Ahmadu Bello University Press.

[4]. Ihugba, O.A., Odii, A., Njoku, A.C. (2013). Challenges and Prospects of Entrepreneurship in Nigeria. Academic Journal of Interdisciplinary Studies, 2(5)

[5]. Mauro, P. (1997). Why Worry about corruption?. International Monetary Fund, Economic issues 6

[6]. Njeze, Cally C.O. (1978). Oil Concessions and Land Acquisition in Nigeria. PhD thesis, University of Cambridge, Obiajuru, I. (2012). What the Nigerian entrepreneur needs to excel. Punch Newspaper, August 16

[7]. Phia Steyn.Oil Exploration In Colonial Nigeria C.1903-1958.University of Stirling Sagagi, M.S. (2005). The paradox of oil revenue and wealth creation in Nigeria. Bayero Business Review. 1(1). 